\title{
Mycoflora and Mycotoxigenic Moulds of Pistachio Nuts for Human Consumption in the Sultanate of Oman
}

\author{
A. E. Elshafie, N. S. Al-Shally
}

Department of Biology, College of Science, Sultan Qaboos University, P.O.Box 36 , Al-Khod 123, Muscat, Sultanate of Oman.

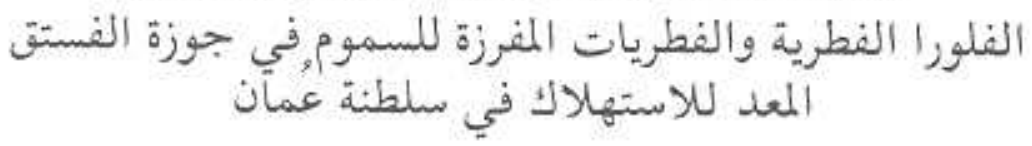

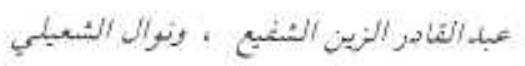

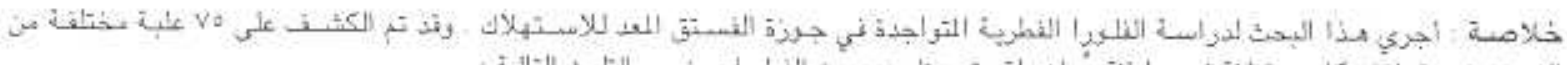

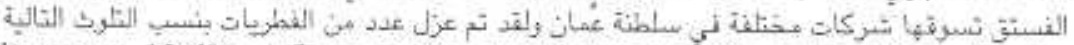
Aspergillus niger $14.8 \%$. Penicillium spp. $13.6 \%$, A.flavus $9.7 \%$, A. nidulans $1.6 \%$, and $<1 \%$ for Cladosporium cladosporoides, Alternaria alternata. Aspergillus ochraceus, and Ulocladium consortiale:

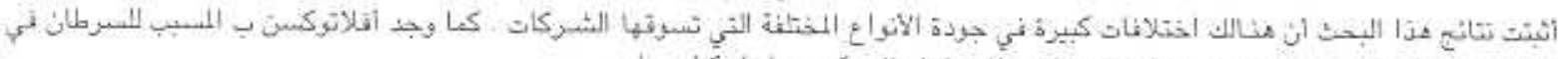

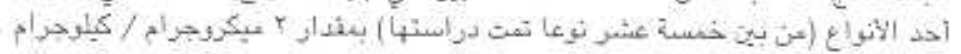

ABSTRACT: Mycoflora of 75 cans of different batches and brands of pistachio nuts purchased in the Sultanate of Oman was studied. A number of fungi were isolated, with pereentages of contaminated nuts [average between brands ] as follows :

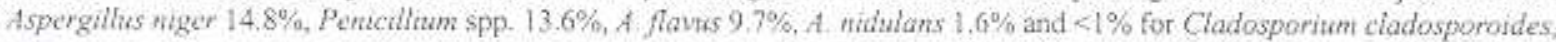
Altemaria altemaia, A ochraceus and Vlocladtum consortiale. Significant differences were found among the batches and brands contaminated by A. farves. Aflatoxin $\mathrm{B}_{1}$ was found only in one sample out of 15 assayed at a level of $2 \mathrm{ug} / \mathrm{kg}$.

$\mathrm{T}$ he endocarp (the shells) of pistachio fruits (Pistacia vera $L$, naturally splits at maturity along its suture, a highly desirable trait as the nuts are usually marketed in the shell to be opened by hand. Contamination of pistachio nuts by toxigenic fungi is most likely to occur in the field as well as during poor storage and processing conditions. Herperkan er al. (1994) reported that mould count of pistachio nuts surveryed in Turkey was in the range of $10^{3}-10^{4}$ ofu $\mathrm{g}^{-1}$ and $10^{5}-10^{6} \mathrm{cfu} \mathrm{g}^{-1}$ for harvest and storage samples respectively. Doster and Michailides (1994) reported a total of 14 Aspergillus species isolated from pistachio nut from 11 commercial orchards in California, USA. Schatzki and Pan (1996) measured the distribution of aflatoxins concentration in 19 processed streams of pistachio nuts in USA and concluded that all aflatoxins found arise in the orchard. It appears that the source of contamination of pistachio nut in the orchards is due to the contamination and sporulation of fungi in pistachio litter (Doster and Michailides, 1994).

Freshly harvested nuts are usually dehulled manually or mechanically. Most countries dry the nuts while they are in the hull, store them for sometime, and later soak them in water to ease the removal of the hulls (Woodroof,
1979). Depending upon the environmental conditions of nut processing contamination may occur. The probability of the contamination of pistachio nuts during storage and distribution is higher than other nuts that do not split open at maturity (Herperkan et al., 1994). Mycotoxins are a group of highly poisonous metabolites produced by different fungi growing on crops or their products. They were isolated from different sources in different parts of the world including food and feed (Sanchis et al, 1986), wheat (Abramson et al., 1990), nuts and oilseeds (Pitt et al., 1993) and groundnut (Awuah and Kpodo, 1996). In the Arabian countries mycotoxins were studied in a number of crops including rice (Abdel-Hafez et al., 1987); hazelnut and walnut (Abdel-Hafez and Saber, 1993), dried fruits (Zohri and Abdel-Gawad, 1993). And tobacco (El-Maghraby and Abdel-Sater, 1993). Aflatoxins which are potentially carcinogenic metabolites of A. flavis and A. parasiticus have been isolated from a number of sources in the Arabian countries that include groundnuts (Hag Elamin et al., 1988), oilseeds (Elshafie et at., 1991); rotted lemon (Mahmoud and Omar, 1994), onion (Zohri and Abdel-Gawad, 1993), and human and camel milk (Saad et al., 1989, 1995). 
Little information has been published on mycotoxins and mycoflora of pistachio nuts (Mojtahedi et al., 1979; Bilgrami, 1994; Doster and Michailides, 1994; Herperkan et al., 1994; Schatzki and Pan,1996). Most of the studies dealt with pistachio nuts in conjunction with other kinds of nuts (Abdel-Gawad and Zohri, 1993; Jimenez et al., 1991; Steiner et al, 1992; Tabata et al, 1993).

In the Sultanate of Oman pistachio nuts are a popular snack, eaten salted and roasted and are traditionally added to Omani halwa (sweet) which is consumed daily with coffee by most families. Shelled and split-shells of pistachio nuts have a good market and they are sold unpacked or in cans under various brand names. The mycoflora and mycotoxins of pistachio nut have not previously been investigated in the Sultanate of Oman. This work investigates the frequency of the mycotoxigenic fungi of samples from different brands and batches of pistachio nuts purchased in retail markets in Muscat area, Sultanate of Oman, that were ready for consumption. Little emphasis has been put on the distribution of the various mycotoxins, instead, only aflatoxin has been investigated. It is believed that it is a more rational approach to identify the mycoflora and mycotoxigenic species of a sample rather than the determination of the hundreds mycotoxins by methods that differ greatly, and others that still need to be developed (Chang-Yen and Bidasee, 1992).

\section{Materials and Methods}

SAMPLE COLLECTION: In the present study five known commercial brands of pistachio nuts available in the retail markets that were ready for human consumption were investigated. Four were vacuum packed while the fifth was unpacked, cheaper and sold by weight. Three batches of each brand having different production and expiry dates were purchased. Each batch consisted of five cans of nuts each containing $140 \mathrm{~g}$ of nuts The nuts were unshelled under aseptic conditions and 49 nuts were placed onto seven petri dishes containing Malt Extract Agar. A total of 735 of nuts per brand were examined. The petri dishes were incubated at room temperature at $20^{\circ} \mathrm{C} \pm 2^{\circ} \mathrm{C}$ for 7 to 10 days, During this period the Petri dishes were examined daily and fungi developing and sporulating on or around the nuts were isolated and identified immediately. Slow growing and nonsporulating fungi were isolated, subcultured in Malt extract agar and were identified later. Identification was carried out using the keys of Ellis (1971, 1976), Moubasher (1993), Raper and Fennel (1965) and Samson and Pitt (1985).

EXTRACTION OF AFLATOXINS BY ELISA METHOD: A variety of methods are available to extract aflatoxins from seeds and foodstuff but are laborious and time consuming.
The Easi-Extract Column (TD110 Oxoid) is a commercially available extraction column. It involves the binding of aflatoxins in a liquid extract to highly specific monoclonal antibodies contained within a small affinity column. The method is simple, high specific, reliable and can be performed much more rapidly than traditional methods (Candlish et al, 1988, 1991).

The sample to be tested was pulverized with a mortar and pestle. Ten grams of the ground sample was mixed with $20 \mathrm{ml}$ of acetonitrile/water (3:2) in a $250 \mathrm{ml}$ beaker for 2 minutes. The mixed sample was then centrifuged at approximately $800 \mathrm{~g}$ [av.] for 10 minutes at room temperature, $2 \mathrm{ml}$ of the extract supernatant was diluted with $46 \mathrm{ml}$ of phosphate buffered saline, the diluted extract was placed in $50 \mathrm{ml}$ syringe barrel from which the plunger was removed, then the plunger was replaced and the extract was pushed through the Easi-Extract Column TD110 that was attached to the syringe barrel. The bound aflatoxins in the column were eluted with $2 \mathrm{ml}$ methanol, the eluent were applied to chromatoplates which were developed in a solvent system of chloroform acetone (9:1). Aflatoxins $B_{1}, B_{2}, G_{1}, G_{2}$ (Sigma, England) were used as standards. One sample from each batch of each branch was analyzed for aflatoxins. Each sample was a mixture of five cans (total of 15 samples representing 5 brands, 15 batches and 75 cans) were analyzed. A detection limit of $2 \mathrm{ug} / \mathrm{kg}$ was chosen in accordance with Oxoid instruction leaflet (Oxoidi Total Aflatoxin EasiExtract Column TD 110. Oxoid Ltd.). Aflatoxins were qualified by visually comparing the intensities of fluorescence of the extract spots with that of the standard after suitable dilutions. The concentration of the aflatoxin in the sample $(\mu \mathrm{g} / \mathrm{kg})$ was calculated according to Singh et al., (1991) by the formula

$$
\mathrm{S} \times \mathrm{Y} \times \mathrm{V} / \mathrm{W} \times \mathrm{Z}
$$

where

$S=$ Volume of aflatoxin standard, in $\mu \mathrm{l}$ of equivalent intensity to $\mathrm{Z} \mu \mathrm{l}$ of sample

$\mathrm{Y}=$ Concentration of aflatoxin standard in $\mu \mathrm{g} / \mathrm{ml}$

$\mathrm{V}=$ Volume of solvent in $\mu \mathrm{I}$ required to elute the extract

$Z=$ Volume of sample extract, in $\mu 1$ required to give fluorescence intensity comparable to that of $5 \mu$ of the standard

$\mathrm{W}=$ Weight of original sample in $\mathrm{g}$, contained in the final extract 


\section{TABLE}

\section{Percentage Frequency of Fungal Contamination in Different Brands of Pistachio Nuts.}

\section{BRANDS}

FUNG!

$\begin{array}{llll}1 & 2 & 3 & 4\end{array}$

$\%$

AVERAGE IN

ALL BRANDS

\begin{tabular}{lllllll}
\cline { 2 - 6 } A niger & 8.3 & 4.5 & 5.8 & 40.7 & 1.4 .8 & 14.8 \\
Penicillium spp. & 8.6 & 27.7 & 6.7 & 12.9 & 11.9 & 13.6 \\
A flavus & 4.9 & 15.5 & 1.1 & 13.0 & 14 & 9.7 \\
A nidulans & 2.3 & 4.8 & 0.4 & 0.22 & 0.27 & 1.6 \\
C. cladosporordes & 0 & 0.53 & 0.27 & 3.8 & 0.13 & 0.95 \\
A alternata & 0.27 & 0 & 1.1 & 0.27 & 0.13 & 0.35 \\
A ochraceus & 0.27 & 0 & 0.40 & 0.13 & 0.40 & 0.24 \\
U. consortiale & 0 & 0 & 0.13 & 0 & 0.53 & 0.13 \\
\hline
\end{tabular}

\section{Results and Discussion}

The level of fungal contamination in the different brands of pistachio nuts studied is shown in Table 1. Aspergillus niger van Tieghem was the predominant species and was isolated from all the brands with an overall average frequency of $14.8 \%$ of nuts in the brands. Penicillium spp.were prevalent in all brands studied with an overall average frequency of $13.6 \%$ of nuts. A. flavus was also found in all brands with an overall average frequency of $9.7 \%$ of nuts. This is in agreement with earlier findings (Gawad and Zohri, 1993). Jimenez et al. (1991) studied 32 samples of pistachio nuts (1600 kernels) in Spain and found that the percentages of infected kernels of pistachio nuts were $9.8 \%$ for $A$. flavus, $21.4 \%$ for A. niger, and $18.6 \%$ for Penicillium spp. Heperkan and Aran (1994) reported that the predominant flora on stored pistachio nuts were Aspergillus (A, niger represented the majority of Aspergillus species). Penicillium and Cladosporium, while Bilgrami and Ghaffar (1994) reported that the predominant species were $A$. flavis and $A$. niger. In the present study, $A$. nidulans was found in all brands but at lower percentage (1.6\%) compared with $A$. niger and $A$. flavus. The percentage frequency of $C$. cladosporoides, A. altemata, $A$. ochraceus and $U$. consortiale were found to be less than $1 \%$ and were absent in some samples.

The number of colonies of $A$. flavtus isolates per can sample in the brands shown in Table 2 [was analyzed using a one-way ANOVA test]. The analysis showed a significant difference between the brands $(\mathrm{P}<0.05)$. The table shows the highest contamination by A. flaves in brand 2. The lowest level of contamination is shown by brand 3. Turkey"s test showed similarity in contamination between brands 1 and 3 and between brands 2 and 4 .

BATCHES OF PISTACHIO NUTS: The companies marketing pistachio nuts release their products in batches at different times. The country of origin of the pistachio nuts were not indicated on the cans. One would assume that if the pistachio nuts are always coming from the same source and are processed under the same conditions, the percentage contamination of the batches by $A$. flavus as well as other fungi would be constant. In this study significant differences were found among all the batches contaminated by A. flavus except brand 3 (Table 2). A one-way ANOVA test showed that there was significant difference at the levels of d.f. $=14, F=3.6, P<0.05$; d.f. $=14, \mathrm{~F}=15.3, \mathrm{P}<0.00$; d.f $=14, \mathrm{~F}=14.3, \mathrm{P}<.00$; and d.f. $=14, F=4.4, P<0.03$ for the batches of the brands 1 , 2,4 and 5 respectively. These significant differences among the batches may indicate differences in the quality of the pistachio nuts as far as A. flartis contamination is concerned. Studies on pistachio nuts in Japan (Tabata et al., 1993) have shown that the difference in aflatoxin contamination was related to the country of origin where aflatoxin positive samples were found in samples from Iran where as samples from USA were free of aflatoxin.

ISOLATES AND TOXIGENIC STRAINS: Many species of Aspergillus and Penicillium are known to produce 
TABLE 2

The Number of A. Flavus Isolates in Batches and in Brands.

\begin{tabular}{|c|c|c|c|c|c|c|c|}
\hline Brands & Batches & Can 1 & Can 2 & Can 3 & Can 4 & Can 5 & $\begin{array}{l}\text { Anova } \\
\text { test }\end{array}$ \\
\hline & 1 & 3 & 3 & 3 & 4 & 3 & d. $f=14$ \\
\hline & 2 & 2 & 2 & 1 & 6 & 3 & $F=3.6$ \\
\hline \multirow[t]{3}{*}{1} & 3 & 2 & 1 & 2 & 0 & 1 & $P<0.05$ \\
\hline & 1 & 23 & 12 & 10 & 17 & 11 & d. $\mathrm{f}=14$ \\
\hline & 2 & 6 & 4 & 5 & 9 & 15 & $\mathrm{~F}=15.3$ \\
\hline \multirow[t]{3}{*}{2} & 3 & 1 & 1 & 0 & 0 & 0 & $P<0.00$ \\
\hline & 1 & 2 & 0 & 0 & 0 & 0 & No \\
\hline & 2 & 0 & 1 & 0 & 2 & 1 & significant \\
\hline \multirow[t]{3}{*}{3} & 3 & 0 & 0 & 0 & 1 & 1 & difference \\
\hline & 1 & 2 & 18 & 18 & 27 & 20 & d. $f=14$ \\
\hline & 2 & 0 & 3 & 1 & 0 & 0 & $F=14.36$ \\
\hline \multirow[t]{3}{*}{4} & 3 & 0 & 3 & 0 & 1 & 3 & $P<0.00$ \\
\hline & 1 & 11 & 14 & 6 & 2 & 10 & d. $f=14$ \\
\hline & 2 & 13 & 10 & 12 & 0 & 14 & $F=4.4$ \\
\hline 5 & 3 & 4 & 1 & 3 & 1 & 12 & $P<0.03$ \\
\hline
\end{tabular}

mycotoxins. In the present study, potentially toxigenic fungi such as $A$. flavus $(9.7 \%)$, A, ochraceus $(0.4 \%), A$. nidulans $(1.6 \%)$, Penicillium spp. $(13.6 \%)$ and $A$. alternata $(0.35 \%)$ have been found in the different brands studied (Table 1). The presence of these potentially toxigenic moulds in pistachio nuts or any other food product indicate the potential for mycotoxin contamination. If these fungi find suitable conditions for their growth they produce mycotoxins. Although not all A. flavus strains are aflatoxigenic, a high incidence of aflatoxigenic strains are usually found among the isolates. In Israel, 1626 isolates of A. flavus from groundnuts were examined and $89.6 \%$ of them were found to be aflatoxigenic (Joffe, 1969). Lisker et al. (1993) surveyed 17 reports collected from works performed all over the world and found that 14 of them showed $50-100 \%$ of the isolates to be aflatoxigenic. They also found that $77 \%$ of the two hundred strains they isolated from groundnuts were aflatoxigenic. In Australia, $49 \%$ of the strains of A. flavus in animal feed were found aflatoxigenic (Cannole et al., 1981), In Turkey, $35,2 \%$ of the isolated A.flavus [18/51] were found to be toxigenic (Herperkan et al, 1994).
Aflatoxins in Pistachio NUtS: Pistachio nuts have been reported to be contaminated by aflatoxins at different ratios and concentrations. In Switzerland Steiner et al., (1992) found that the ratio of 4700 uncontaminated pistachio nuts kernels to one kernel containing aflatoxin $\mathrm{B}_{1}$ at a level ranging from $8 \mathrm{ppb}$ to $61 \mathrm{ppb}$. In Japan (Tabata et al., 1993) of 165 samples of pistachio nuts examined, 5 were found containing aflatoxin at an average of $323 \mathrm{ppb}$ for $\mathrm{B}_{1}, 58 \mathrm{ppb}$ for $\mathrm{B}_{2}$. In the present investigation, only one sample out of 15 assayed was found to contain aflatoxin $B_{1}$ at a level of $20 \mathrm{ppb}$. Similar results were reported in which aflatoxins were found in only one sample [13 ppb] of pistachio nuts from 30 samples surveyed (Burdaspal et al., 1990). In the USA aflatoxins were detected in 11 of 17 orchards studied at a level ranging from 0.1 to 958 ppb (Doster and Michaillides, 1994). No aflatoxins were found in pistachio nuts surveyed in Saudi Arabia (Abdel-Gawad and Zohri, 1993) and Turkey (Herperkan et al., 1994).

The presence of aflatoxins or potential mycotoxin producing fungi in pistachio nuts is a potential health hazard. Many countries regulated the maximum permissible levels of aflatoxins in foods, as follows: 20 


\section{MYCOFLORA AND MYCOTOXIGENIC MOULDS OF PISTACHIO NUTS}

ppb in the USA, 15 ppb in Canada, 10 ppb in France, UK and Japan, and $5 \mathrm{ppb}$ in Australia (Tabata et al., 1993).

\section{Acknowledgements}

We wish to thank the technical staff of the Biology Department, Sultan Qaboos University for their technical help. We thank Dr. E. K. Elsheikh of the Mathematics and Statistics Department, Sultan Qaboos. University for his kind help.

\section{References}

ABDEL-GAWAD, K. M and A.A. ZOHRI, 1993, Fungal flora and mycotoxins of six kinds of nut secds for human consumption in Saude Arabia. Mycopathologia 124, 55-64.

ABDEL,-HAFEZ, A.I.I and S.M. SABER, 1993. Mycoflora and mycotoxin of hazelnut (Corylus avellana L.) And walnut (Juglans regia L.) seeds in Egypt. Zentralblatt Fuer Microbiologie 148(2): 137-147.

ABDEL-HAFEZ, S.1.1, L.A. EL-KADY, M.B. MAZENI, and OM.O. EL MAGHRABY, 1987. Mycotlora and trichothecene toxins of paddy grains from Egypt. Mycopatholgsa 100: 103. 112.

ABRAMSON, D., R.N. SINHA and J.T. MILLS, 1990. Mycotoxin formation in HY.320 wheat during storage at 15 and $19 \%$ moisture content. Mycopathologia 111:181-189

AWUAH, R, and K.A. KPODO, 1996 High incidence of Aspergillus flaves and aflatoxins in stored groundnut in Ghana and the use of a microbial assay to assess the inhibitory effects of plant extracts on aflatoxin synthesis. Mycopathologia 134 $109-114$

BILGRAMI, Z and A. GHAFFAR, 1994. Fangi assocaited with Pistachia vera Pakistan Journal of Botany 26(2), 221-228.

BURDASPAI, P. A.;A. GOROSTIDI and M.C. TEJEDOR, 1990 A survey of the occurrence of aflatoxins in edible nuts in Spatn. Abstract, International Symposium and Workshop on Food Contamination. Mycotoxins and Phytotoxins 4-15 November 1990. Cairo, Egypt.

CANDLISH, A.A.C.A.HAYNES and W.H.STIMSON, 1988. Detection and determination of aflatoxin using affinity chromatography, International Journal of Food Science and Technology 23, 479-485.

CANDLISH, A. A. G.M.K.FARAJ;G. HARRAN and J.E. SMITH, 1991. Imununoaffinity column chromatography for detection of total aflatoxins in experimental stations. Biotechnology Techniques 5(5), 317-322.

CANNOLE, M D.,B.J BLANEY and T. MCEWAN, 1981. Mycotoxins in animal feeds and toxic fungi in Qucensland 1971-80. Australian Veterinary Journal 57, 314-318.

CHANG-YEN, 1. and K. BIDASEE, 1992. Mycoflora and mycotoxin-producing potential of fungi from poultry feeds and feed ingredients in Trinidad. Journal of Science Food Agriculture 60, 283-286

DOSTER, M. A. and T.J. MICHAILIDES, 1994. Aspergillus molds and aflatoxins in pistachio nuts in California. Phytopathology 84(6), 583-590.

DOSTER, M. A and T.J. MICHAILIDES, 1994. Development of Aspergillus molds in litter from pistachio trees. Plant disease $78(4), 393.397$

ELLIS, M.B. 1971. Dematiaceoss hyphomycetes. Commonwealth Mycological Institute, Kew, Surrey, England.

ELLIS, M.B. 1976. More Dematiaceous hyphomcetes.
Commonwealth Mycological Institute, Kew, Surrey, England.

EL MAGRABY, O.M.O. and M.A ABDEL-SATER, 1993. Mycoflora and natural occurrence of mycotoxins in tobacco from cigarettes in Egypt. Zentralblatt Fuer Mikrohiologie 148(4): $253-264$

ELSHAFIE, A.E., K.M. ABDELBASIT and M.H. ABDALLA, 1991. Allatoxim production and morphological characters of Aspergillus favtus isolates from Sudan. Irdian J Microbiol Ecol. 2: 79.85 .

HAG ELAIN, N.H., A.M. ABDEL-RAHIM and A.E. KHALID, 1988. Aflatoxin contamination of groundnuts in Sudan. Mycopathologia 104:25-31

HEPERKAN, D.V. ARAN and M.AYFER, 1994. Mycoflora and aflatoxin contamination in shelled pistachio nuts. Journal of the Science of Food and Agriculture 66(3), 273-278.

JMENEZ, M.R. MATEO;A. QUEROL;T HUERTA and E. HERNANDEZ, 1991. Mycotoxins and mycotoxigenic moulds in nuts and sunflower seeds for human consumption. Mycopathologia 115, 121-127

JOFFE, A Z 1969. Aflatoxin produced by 1626 isolates of Aspergillus flaves from groundnut kernels and soil in Israel. Nature 221, 492.

LISKER, N.,R. MICHAELI and Z.R. FRANK, 1993, Mycotoxigenic potential of Aspergillus fiavus strains isolated from groundnuts growing in Istael. Mycopathologia 122, 177-183.

MAHMOUD, A.L.E. and S.A. OMAR, 1994. Enzymatic activity and mycotoxin producing potential of fungi isolated from rotted lemon. Cryprogame Mycologie 15(2) 117-127.

MOHATAHEDI, E, C.J RABIE, A. LUBBEN, M STEYN and D DANESH, 1979. Toxic aspergilli from pistachio nuts Wycopathologia 67(2): 123-127

MOUBASHER, A H. 1993. Soil Fungi in Qatar and Other Arab Countries. The Center for Scientific and Applied Research. University of Qatar, Doha, Qatar.

PITT, J.I, A.D. HOCKING, K BHUDHASAMAl, B.F. MISCAMBLE, KA. WHEELER and P. TANBOON-EK. 1993. The normal mycoflora of commodities from Thailand. 1. Nuts and oilseeds. International fowrnal of Food Microbiology $20: 211-226$

RAPER, K.B. and D.1. FENNEL, 1965. The Genus Aspergillus The Willtams and Wilkins Company, Baltimore, U.S.A.

SAAD, A.M., A.M. ABDELGADIR and MO. MOSS, 1989 Aflatoxin in human and camel milk in Abu Dhabi, United Arab Emirates: Mycotoxin Research 5: 57-60.

SAAD, A.M, A.M ABDELGADIR and M.O. MOSS, 1995 Exposure of infants to aflatoxin $\mathrm{M}_{1}$ from mother's breast milk in Abu Dhabi, U.A.E. Food Additives and Contaminants 12(2): $255-261$.

SAMSON, R.A. and J.I. PITT, 1985. Advances in Pentcillium and Aspergillus Systematics. New York: Plenum Press.

SANCHIS, V., N. SALA., A. PALOMES, P SANTAMARINA and P.A. BURDASPAL, 1986. Occurrence of aflatoxin and aflatoxigenie moulds in foods and fecds in Spain. Journal of Food Protection 49(6): 445-448.

SCHATZKI, T. F and J.L. PAN, 1996, Distribution of aflatoxin in pistachio. 3. Distribution in pistachio process streams. Journal of Agriculture and Food Chemistry 44(4), 1076-1084

SINGH, K, J.C. FRISAUD, U. THRANE and S.B. MATHUR, 1991. An illustrated manual of some seed-borne Aspergilli, Fusaria, Penicillia and their mycotoxins. Danish Government Institute of Seed Pathology for Developing Countries, Hellerup, Denmark.

STEINER, W.E., K. BRUNSCHWEILER, E. LEIMBACHER and R.SCHNEIDER, 1992. Aflatoxins and fluorescence in Brazil nuts and pistachio nuts. Journal of Agriculture and Food Chemistry 40(12): 2453-2457.

TABATA. S., H, KAMIMURA, A. IBE, H. HASHIMOTO, M. 


\section{A. E. ELSHAFIE AND N. S. AL-SHALLY}

IIDA, Y, TAMURA and T.NISHIMA, 1993. Aflatoxin contamination in foods and foodstuffs in Tokyo: 1986-1990. Jostrnal of AOAC International 76(1): 32-35,

WOODROOF, J. G. 1979. Tree nuts: production, processing and products. 2nd edition, AVI Publishing Company Inc, Westport, Connecticut.
ZOHRI, A.A. and K.M. ABDEL-GAWAD, 1993. Survey of mycoflora and mycotoxins of some dried fruits in Egypt. Journal of Basic Microbiology 33(4): 279-288.

ZOHRI, A.A., S.M. SABER, K.M. ABDEL-GAWAD, 1992. Fungai flora and mycotoxins associated with onion (Allum cepa L.) in Egypt. Korean Journal of Mycology 20(4): 302-308.

Received 23 March 1997

Accepted 16 April 1998 